\title{
Seed-Colonizing Microbes from Municipal Biosolids Compost Suppress Pythium ultimum Damping-Off on Different Plant Species
}

\author{
M.-H. Chen and E. B. Nelson
}

Cornell University, Department of Plant Pathology and Plant-Microbe Biology, 334 Plant Science Building, Ithaca, NY 14853-4203. Current address of first author: Asia University, Department of Biotechnology, 500 Lioufeng Rd., Wufeng, Taichung 41354, Taiwan. Accepted for publication 22 May 2008.

\begin{abstract}
Chen, M-.H., and Nelson, E. B. 2008. Seed-colonizing microbes from municipal biosolids compost suppress Pythium ultimum damping-off on different plant species. Phytopathology 98:1012-1018.

Composts are known for their suppressive properties toward many different seed- and root-infecting pathogens and diseases. Although disease and pathogen suppression induced by composts is believed to be mediated by microbial activities, the nature of the microbial species and processes responsible for suppressiveness remain unknown. We demonstrated previously that seed-colonizing microbial consortia from leaf compost could explain the observed levels of Pythium ultimum-induced damping-off suppression on cotton. The aim of the present work was to

were observed on cucumber, wheat, and pea at water potentials of $-2 \mathrm{kPa}$. The suppression of damping-off on cucumber and wheat could be eliminated by autoclaving the compost prior to sowing. High levels of suppressiveness were expressed both on cucumber and on wheat seed surfaces within $8 \mathrm{~h}$ of sowing. However, the expression of damping-off suppression on the surface of pea seeds was inconsistent and highly variable. Our results demonstrate that compost-induced suppression of $P$. ultimum damping-off of cucumber and wheat can be explained by the microbial consortia colonizing seeds within $8 \mathrm{~h}$ of sowing. These results further suggest that disease suppression in composts is related to microbial species that interact with the pathogen in its infection court and not in the bulk compost.
\end{abstract} determine whether seed-colonizing microbial consortia could explain Pythium damping-off suppression in municipal biosolids compost on three different plant species. Significant levels of disease suppression
Additional keywords: oomycete ecology, spermosphere, suppressive soils.
Disease suppressive properties of compost amendments are well known and the spectrum of pathogens and diseases that can be effectively managed by compost amendments has been well documented $(10,15,18,28)$. Many studies of compost-induced disease suppression have focused on diseases caused by Pythium species (28) where suppressiveness has been linked directly to microbial populations and activities (10). However, little is known of the specific microbes and processes involved in disease suppression.

Various approaches have been used to identify the specific microbes that contribute to disease suppressiveness in composts and suppressive soils (3). Traditionally, many of these approaches have focused on microbial taxa associated directly with the substrate $(9,14,40$, and references therein). However, a problem with this strategy is that the vast majority of these microbes have little or nothing to do with the disease-suppressive phenotype. More directed approaches for identifying disease suppressive microbes that take advantage of correlations between differential levels of disease suppression with population changes of specific microbes have been proposed (4). Although differential levels of Pythium damping-off suppression may be obtained by varying the feedstock $(31,37)$, incorporation rate $(42)$, temperature (1), or Pythium species $(1,31)$, disease suppression under these differential conditions may not always be correlated directly with population levels of specific microbes because of regulatory mechanisms that may affect the expression of suppressive properties (44).

Corresponding author: E. B. Nelson; E-mail address: ebn1@ cornell.edu

doi:10.1094/PHYTO-98-9-1012

(c) 2008 The American Phytopathological Society
A successful approach for identifying disease-suppressive microbes, as illustrated by studies of the take all decline phenomenon (43), is to look specifically at microbial taxa that associate directly with the plant infection court $(2,22,30,36)$. Plants form intimate associations with microbial communities that can influence the behavior and activity of soil pathogens $(11,12)$. Although it is well known that spermosphere- and rhizosphere-associated microbial communities influence disease development on different plant genotypes $(21,34)$, the role of the host plant in affecting compost-induced disease suppression remains poorly characterized. Because seeds represent the primary infection court for Pythium species (23), spermosphere microbial communities are likely to have strong effects on disease suppression. This was demonstrated previously with leaf composts in which Pythium damping-off suppression was expressed on cottonseed surfaces within the first few hours of sowing seed (22). The microbial consortia that associated with cottonseed shortly after sowing accounted for all of the disease suppression observed. These observations, coupled with observations of differential damping-off suppression among plant species when seeds are treated with individual disease-suppressive microbes (20,34, $35,44)$, further points to the important role of seed-colonizing microbes in disease suppression and the potentially important role of the host plant in regulating the disease suppressive activities of seed-associated microbes.

The aim of our present study was to determine the suppressiveness of a municipal biosolids compost to Pythium dampingoff of cucumber, wheat, and pea as a means of understanding whether (i) different plant species support compost-induced Pythium damping-off suppression and (ii) compost microbes that colonize seeds during early stages of seed germination can adequately explain levels of damping-off suppression observed on each plant species. 


\section{MATERIALS AND METHODS}

Composts and plant material. A municipal biosolids compost was collected from a composting facility in the village of Endicott, NY, in 2005 and used throughout this study. The general properties of biosolids composts produced from this facility have been described previously (9). At the commencement of this study, the compost was sieved through a $2 \mathrm{~mm}$ screen, placed in $\approx 3$-liter aliquots, and stored at $-20^{\circ} \mathrm{C}$ until use. These smaller subsamples were used to avoid repeated freeze-thaw cycles with the compost material that might severely alter compost microbial communities (41). For all laboratory experiments, each compost was removed from the freezer $24 \mathrm{~h}$ prior to an experiment and mixed with sterile, washed, oven-dried quartz sand sieved to a particle size between 0.5 and $1.0 \mathrm{~mm}$ at a rate of $100 \mathrm{mg}$ (dry weight) of compost per $\mathrm{cm}^{3}$ of mix (total volume). Hereafter, this compost-sand mixture is referred to as "compost medium".

The following plant species were used in our study: cucumber (Cucumis sativus L. 'Marketmore'), wheat (Triticum aestivum L. 'Batavia'), and pea (Pisum sativum L. 'Maxigold'). Cucumber and pea seeds were obtained from a commercial seed company (Johnny's Selected Seeds) whereas wheat seeds were kindly provided by M. Sorrels, Department of Plant Breeding and Genetics, Cornell University. All seeds were stored at room temperature.

Production of $\boldsymbol{P}$. ultimum sporangia. Sporangia of $P$. ultimum were used as inoculum in all seedling bioassay experiments. $P$. ultimum isolate $\mathrm{P} 4$ was maintained on solid $\mathrm{SM}+\mathrm{L}$ medium as described previously (39). After 5 days of growth at $27^{\circ} \mathrm{C}$, mycelial disks ( $5 \mathrm{~mm}$ diameter) were excised, placed in sterile petri dishes (9 $\mathrm{cm}$ diameter) and leached for two consecutive 10-min periods in a buffer ( $\mathrm{pH} 5.8$ ) containing $10 \mathrm{mM} \mathrm{Ca}\left(\mathrm{NO}_{3}\right)_{2} \cdot 4 \mathrm{H}_{2} \mathrm{O}$, $4 \mathrm{mM} \mathrm{MgSO} \cdot 7 \mathrm{H}_{2} \mathrm{O}$, and $5 \mathrm{mM} \mathrm{KNO}_{3}$. This was followed by a final 3-h leaching period in darkness. The buffer was replaced after each leaching period. After the final leaching period, the leachate was removed, disks were rinsed twice with sterile water, and then incubated at $24^{\circ} \mathrm{C}$ in darkness for 2 days. This leaching process was used to enhance the formation of $P$. ultimum sporangia $(26,27)$.

Disease suppression bioassays. Bioassays designed to measure compost suppressiveness were set up in fritted glass funnels (600 ml, $9 \mathrm{~cm}$ diameter) to maintain constant water potentials. Each funnel was packed with $75 \mathrm{~cm}^{3}$ of compost medium or sand. An agar disk containing P. ultimum sporangia was then placed on the surface of the medium. A single surface-disinfested cucumber seed was then placed directly onto the agar disk. The funnels were then filled with a final $75 \mathrm{~cm}^{3}$ of compost medium or sand. The medium was saturated with distilled water and adjusted to a water potential of $-2 \mathrm{kPa}$. Noninfested sand and compost medium were used as controls. The entire assembly was incubated at $24^{\circ} \mathrm{C}$ with a $16 \mathrm{~h}$ photoperiod. After 7 days, funnels were scored for percent seedling stand and each emerged seedling was also assessed for shoot height and shoot dry weight. There were three replicates for each treatment, with 10 seedlings per replicate. From our initial results, it was clear that each of the three measures of disease severity mirrored each other (Table 1). We therefore chose to use shoot heights as our measure of disease severity in all subsequent experiments because shoot heights not only reflected observed differences in stand establishment, but they also served as a measure of the stunting that was observed in sand compared with compost medium and also associated with postemergence disease development (Fig. 1).

To verify that damping-off suppression in compost was due to biological factors, the compost was autoclaved at $121^{\circ} \mathrm{C}$ for 30 min on two consecutive days then mixed with sterile sand. Bioassays were set up as described previously and incubated at $-2 \mathrm{kPa}$. Nonautoclaved compost medium and sterile sand served as controls. Bioassays were incubated at $24^{\circ} \mathrm{C}$ for 7 days then shoot heights of each seedling were determined.

Transplant experiments. Transplant experiments similar to those described previously (22) were used to determine how soon suppressiveness was expressed after sowing. Cucumber, wheat, and pea seeds were removed from funnels at $0,8,16$, and $24 \mathrm{~h}$ after sowing. Seeds were rinsed with sterile deionized water to remove any adhering compost or sand and then placed directly on the top of an agar disk containing P. ultimum sporangia in a clean fritted glass funnel containing $75 \mathrm{~cm}^{3}$ of sterile sand. Seeds were then covered with an additional $75 \mathrm{~cm}^{3}$ of sterile sand and the entire bioassay assembly incubated and rated as described previously. There were three replicates for each treatment, with 10 seedlings per replicate.

Pythium damping-off suppression by seed-colonizing microorganisms. Microbial consortia associated with the surface of seeds germinated in compost medium were evaluated for their effects on Pythium damping-off. Fifty seeds of cucumber, wheat, or pea were grown for $8 \mathrm{~h}$ in compost medium, removed, then placed in $10 \mathrm{ml}$ of a $0.1 \%$ sodium pyrophosphate (NaPP) buffer and vortexed for $5 \mathrm{~min}$ to dislodge microbial cells. Cell suspensions were then centrifuged for $15 \mathrm{~min}$ at $8,000 \mathrm{rpm}$ to pellet microbial cells. In some experiments, seeds were vortexed for three additional $5 \mathrm{~min}$ periods, collecting microbial pellets following each vortexing period. The recovered microbial pellets were resuspended in $2 \mathrm{ml}$ of $0.1 \% \mathrm{NaPP}$ buffer. Ten surface disinfested seeds of cucumber, wheat, or pea were placed in these microbial cell suspensions for $30 \mathrm{~min}$. Seeds were then removed and placed adjacent to an agar disk containing $P$. ultimum sporangia in a clean fritted glass funnel containing $75 \mathrm{~cm}^{3}$ of sterile sand. Nontreated seeds served as controls. Seeds were covered with an additional $75 \mathrm{~cm}^{3}$ of sterile sand and the entire bioassay assembly incubated and rated as described previously. In all experiments, seeds sown in sterile sand that was either noninfested or infested with P. ultimum served as positive and negative controls, respectively. There were three replicates for each treatment, with 10 seedlings per replicate.

Statistical analyses. Shoot height, seedling stand, and dry weight of shoot data were analyzed by analysis of variance (ANOVA) procedures using the PROC GLM (general linear models) or mixed model in SAS version 9.1 (SAS Institute, Cary, NC). Means were compared using Tukey's multiple range test.

\section{RESULTS}

Suppression of Pythium damping-off on different hosts. Municipal biosolids compost was suppressive to Pythium damping-off (as measured by shoot height) on all three plant species tested (Fig. 1). Shoot heights of seedlings grown in P. ultimuminfested compost were significantly $(P<0.05)$ greater than shoot heights of seedlings grown in $P$. ultimum-infested sand, in which few seedlings emerged after 7 days and both seeds and radicals were heavily diseased. Mean shoot height of cucumber and wheat

TABLE 1. Comparison of three different metrics for assessing cucumber seedling damping-off in compost medium or sand infested or noninfested with Pythium ultimum sporangia

\begin{tabular}{|c|c|c|c|c|}
\hline \multirow[b]{2}{*}{ Substrate ${ }^{y}$} & \multirow{2}{*}{$\begin{array}{l}\text { Infested } \\
\text { with } P \text {. } \\
\text { ultimum }\end{array}$} & \multicolumn{3}{|c|}{ Damping-off metric } \\
\hline & & $\begin{array}{l}\text { Seedling } \\
\text { stand }(\%)\end{array}$ & $\begin{array}{c}\text { Shoot } \\
\text { height }(\mathrm{mm})\end{array}$ & $\begin{array}{c}\text { Root dry } \\
\text { weight (mg) }\end{array}$ \\
\hline \multirow[t]{2}{*}{ Sand } & - & $100.0 \mathrm{a}^{\mathrm{z}}$ & $57.9 \mathrm{~b}$ & $135.2 \mathrm{ab}$ \\
\hline & + & $0.0 \mathrm{c}$ & $0.0 \mathrm{c}$ & $0.0 \mathrm{c}$ \\
\hline \multirow[t]{2}{*}{ Compost medium } & - & $100.0 \mathrm{a}$ & $68.0 \mathrm{a}$ & $149.1 \mathrm{a}$ \\
\hline & + & $83.3 \mathrm{~b}$ & $52.9 \mathrm{~b}$ & $127.6 \mathrm{~b}$ \\
\hline
\end{tabular}

y Substrates held at a water potential of $-2 \mathrm{kPa}$.

${ }^{\mathrm{z}}$ Numbers in each column followed by the same letter are not significantly different $(P \leq 0.05)$ according to Tukey's multiple range test. 
seedlings grown in infested compost did not differ from that in noninfested sand. Mean cucumber shoot height was 59.9 and $59.6 \mathrm{~mm}$ in infested compost and noninfested sand, respectively, whereas mean wheat shoot height was 119.6 and $89.3 \mathrm{~mm}$, respectively. Mean cucumber shoot height in noninfested compost $(77.6 \mathrm{~mm})$ was significantly greater than the respective mean shoot height in noninfested sand $(59.9 \mathrm{~mm})$. However, mean shoot height of pea and wheat seedlings grown in noninfested compost (54.2 and $114.8 \mathrm{~mm}$, respectively) did not differ from their respective mean shoot height in noninfested sand (51.8 and $119.6 \mathrm{~mm}$, respectively). Mean cucumber and pea shoot height in noninfested compost (77.6 and $54.2 \mathrm{~mm}$, respectively) was significantly greater than the mean shoot height of seedlings grown in infested compost (59.6 and $39.6 \mathrm{~mm}$, respectively). Wheat seedling shoot heights did not differ between infested and noninfested compost (89.3 and $114.8 \mathrm{~mm}$, respectively).

Autoclaving the compost medium eliminated suppressiveness to $P$. ultimum damping-off on all three species (Fig. 2). Significant $(P<0.05)$ reductions in shoot height were observed in infested autoclaved compost medium as compared with the nonautoclaved compost medium. Shoots heights in the infested autoclaved compost medium did not differ from those in infested sand.

Transplant experiments. To identify when seed-colonizing microbial communities became suppressive to Pythium dampingoff, seeds of the three plant species were sown in sand or compost medium for 8,16 , and $24 \mathrm{~h}$ before being transplanted to sterile sand and infested with $P$. ultimum sporangia. Significant $(P<$ 0.05 ) levels of damping-off suppression (as determined by shoot heights) were observed as early as $8 \mathrm{~h}$ after sowing cucumber or wheat seeds in compost (Fig. 3). Suppressiveness was also evident at 16 and $24 \mathrm{~h}$ for cucumber but was not apparent for wheat at these incubation times. Shoot heights among cucumber seeds transplanted from sand to sand did not differ between 8 and $24 \mathrm{~h}$. However, shoot heights from wheat seeds transplanted at 16 and $24 \mathrm{~h}$ after sowing was significantly less than for shoot heights from seeds incubated in sand for $8 \mathrm{~h}$. Shoot heights from pea seeds germinated for 8 to $24 \mathrm{~h}$ in compost did not differ significantly from those germinated in sand for 8 to $24 \mathrm{~h}$ before transplanting to sand. Shoot heights from transplanted cucumber, wheat, and pea seeds did not differ from those of nontransplanted seeds at any incubation period tested. Because suppressiveness was expressed as early as $8 \mathrm{~h}$ on cucumber and wheat seeds, this time period was chosen for subsequent sampling of seed-colonizing microbial consortia.

Suppression of Pythium damping-off by seed-colonizing microorganisms. The consortia of seed-colonizing microbes were recovered from the surface of cucumber, wheat, and pea seeds germinated in compost medium for $8 \mathrm{~h}$ and tested for their ability to protect seeds from damping-off. Cucumber and wheat seeds treated with seed-colonizing microbial consortia yielded seedlings with significantly greater than those from nontreated seeds (Fig. 4). Although microbial consortia dislodged from cucumber seeds following a 5-min vortexing treatment induced a significant level of damping-off suppression as compared with infested sand controls, a significant level of disease suppression remained associated with vortexed seeds. A more aggressive 5-min vortexing treatment eliminated all remaining suppressiveness associated with seeds (data not shown). This vortexing treatment did not lead to seed damage or reduced seedling vigor since germination rates and shoot heights of vortexed seeds did not differ from those of nonvortexed seeds when sown in noninfested sand. Furthermore, additional vortexing treatments up to three
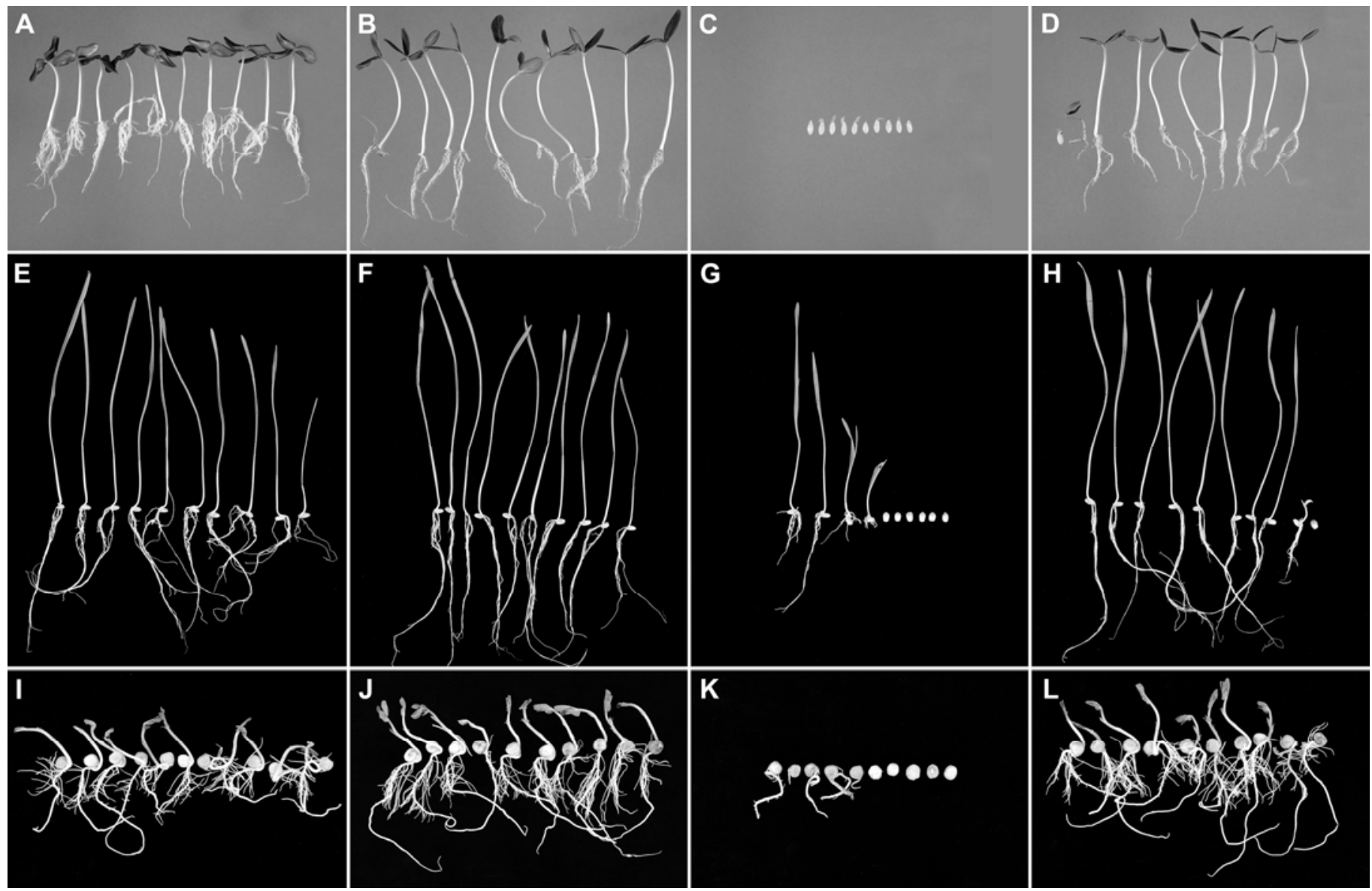

Fig. 1. Seven-day-old seedlings of A to $\mathbf{D}$, cucumber, $\mathbf{E}$ to $\mathbf{H}$, wheat, and $\mathbf{I}$ to $\mathbf{L}$, pea from disease suppression bioassays incubated at $24^{\circ} \mathrm{C}$ and at a water potential of $-2 \mathrm{kPa}$. Treatments are as follows: noninfested sand (A, E, and I), noninfested compost medium (B, F, and $\mathbf{J})$, sand infested with Pythium ultimum sporangia $(\mathbf{C}, \mathbf{G}$, and $\mathbf{K})$, and compost medium infested with $P$. ultimum sporangia $(\mathbf{D}, \mathbf{H}$, and $\mathbf{L})$. 
consecutive 5-min vortexing treatments did not release additional microbial cells that led to Pythium damping-off suppression (data not shown). Shoot heights from wheat seeds treated with the dislodged microbial consortium and challenged with P. ultimum were
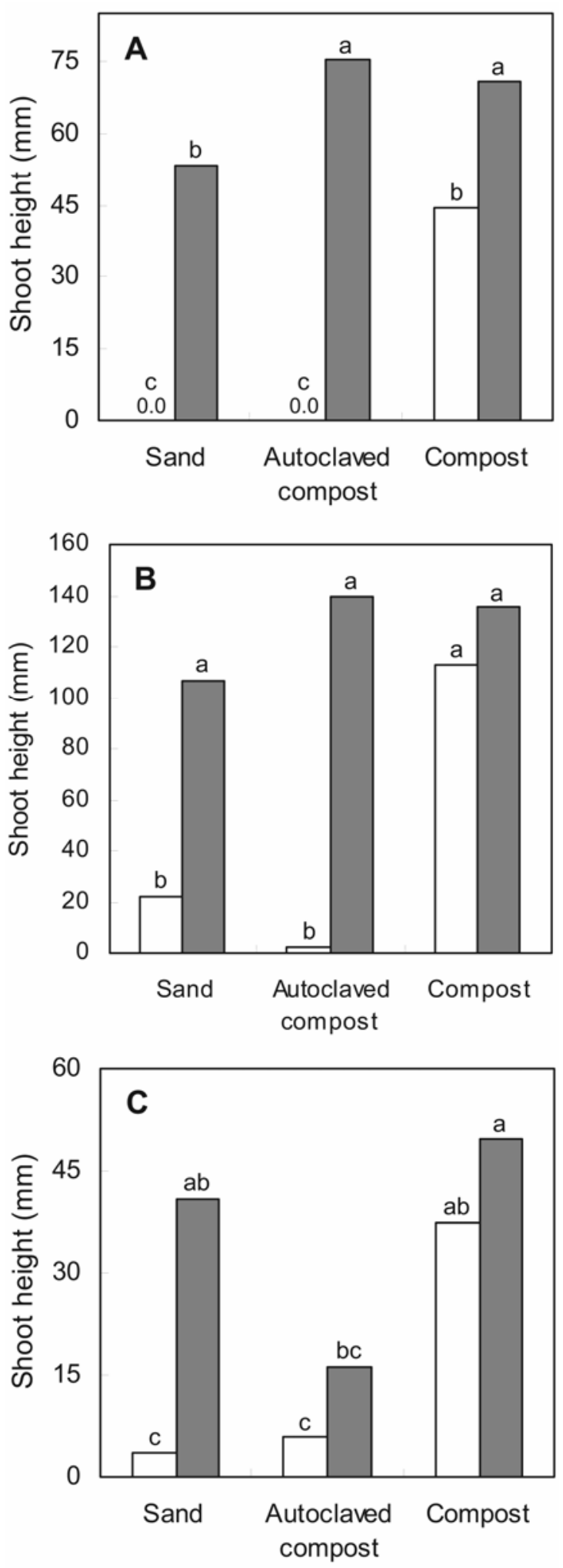

Fig. 2. Suppression of Pythium damping-off of $\mathbf{A}$, cucumber, $\mathbf{B}$, wheat, and $\mathbf{C}$, pea in autoclaved compost medium and in sterile sand. Shoot height $(\mathrm{mm})$ determined after 7 days at $24^{\circ} \mathrm{C}$. Gray bars = noninfested substrates, and white bars $=$ substrates infested with Pythium ultimum. Treatments with the same letter were not significantly different $(P \leq 0.05)$ according to Tukey's multiple range test. significantly greater than those from the lightly vortexed wheat seeds. Shoot heights of seedlings from seeds treated with microbial consortia from pea seeds did not differ from those of seedlings arising from nontreated seeds when challenged with $P$. ultimum.

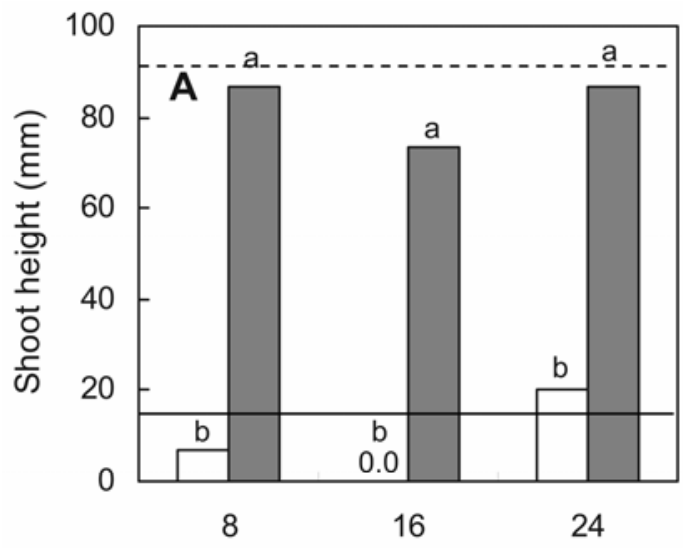

Time before Pythium challenge (h)

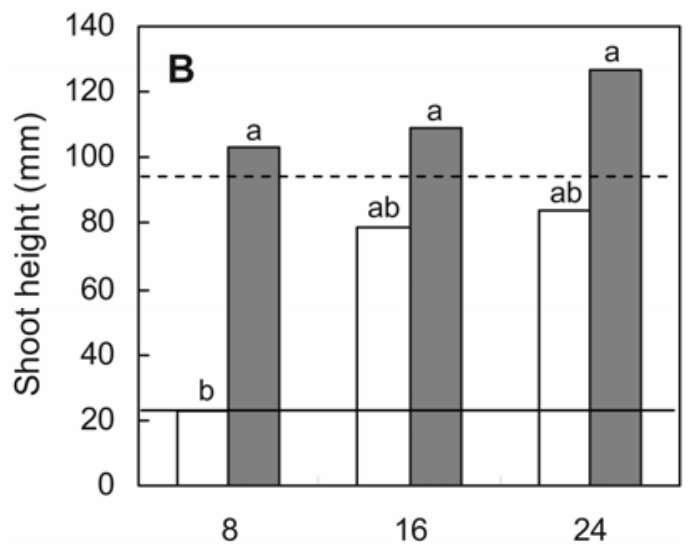

Time before Pythium challenge (h)

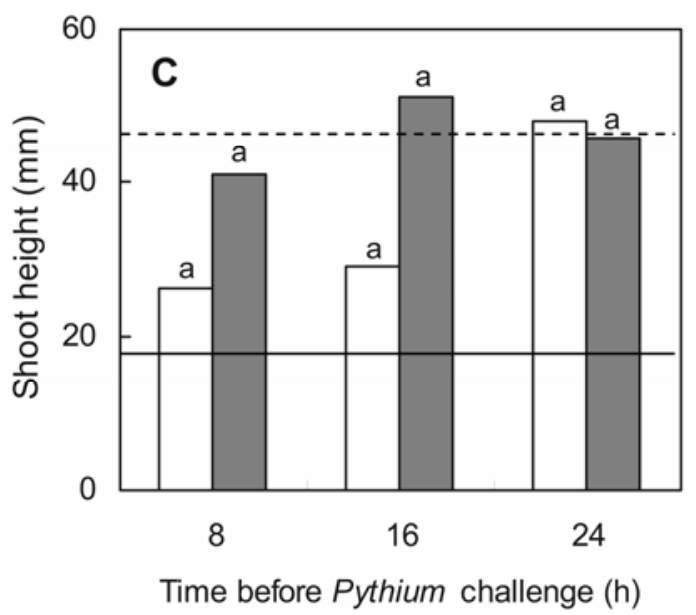

Fig. 3. Influence of germination time in Pythium ultimum-free compost (gray bars) or sand (white bars) on the suppression of Pythium damping-off of $\mathbf{A}$, cucumber, $\mathbf{B}$, wheat, and $\mathbf{C}$, pea when transplanted into sterile sand and challenged with P. ultimum sporangia. Shoot heights $(\mathrm{mm})$ determined after 7 days at $24^{\circ} \mathrm{C}$. Dashed lines represents shoot heights of seedlings challenged with $P$. ultimum immediately after sowing in compost medium (no transplant) and incubated for 7 days. Solid lines represents shoot heights of seedlings challenged with P. ultimum immediately after sowing in sterile sand (no transplant) and incubated for 7 days. Each bar represents the mean of three separate experiments. Treatments with the same letter were not significantly different $(P \leq 0.05)$ according to Tukey's multiple range test. 


\section{DISCUSSION}

Our current work has confirmed the observations of others that municipal biosolids composts suppress Pythium damping-off $(1,13,29)$. Yet, many of the factors that influence and regulate these suppressive properties remain obscure. One of the main aims of our current work was to determine whether compostinduced damping-off suppression was expressed on different plant
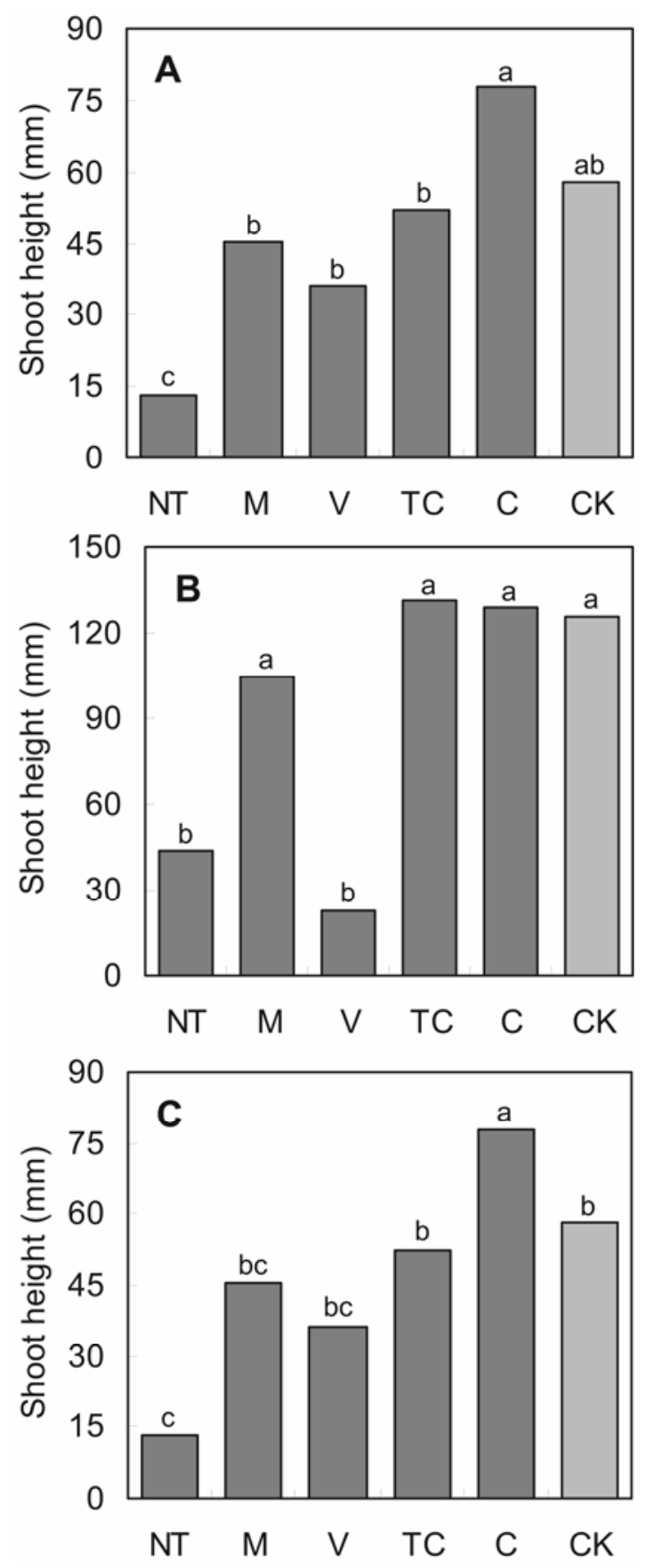

Fig. 4. Suppression of Pythium damping-off by seed-colonizing microbial consortia from $\mathbf{A}$, cucumber, $\mathbf{B}$, wheat, and $\mathbf{C}$, pea seeds germinated in compost for $8 \mathrm{~h}$. Treatments were as follow: NT $=$ nontreated seeds germinated in sterile sand, $\mathrm{M}=$ seeds treated with the microbial pellet dislodged from seeds germinated in compost for $8 \mathrm{~h}$. $\mathrm{V}=$ seeds germinated in compost medium for $8 \mathrm{~h}$ from which microbial communities were removed. $\mathrm{TC}=$ seeds germinated in compost for $8 \mathrm{~h}$ then challenged with $P$. ultimum sporangia. $\mathrm{C}=$ seeds sown in compost and grown for 7 days (seeds challenged with $P$. ultimum sporangia at the time of sowing). $\mathrm{CK}=$ noninoculated seeds (control). Treatments with the same letter were not significantly different $(P \leq 0.05)$ according to Tukey's multiple range test. species. Our results demonstrated that Pythium damping-off suppression in municipal biosolids compost occurred on all three plant species tested. Few previous studies have directly examined Pythium damping-off suppression on more than one host species and in cases where different hosts have been examined, the results are equivocal. Chen et al. (8) found a high level of suppression of Pythium damping-off of both cucumber and two varieties of pea in a composted hardwood bark medium. In other studies with composted household wastes, suppression of Pythium dampingoff was observed on bean, pea, and beets $(32,33)$. However, a municipal biosolids compost was ineffective in suppressing Pythium damping-off of pea or bean caused by $P$. ultimum or $P$. aphanidermatum although a high level of suppression of $\mathrm{P}$. myriotylum damping-off of bean was observed (19).

Previous studies from our laboratory indicated that the suppression of Pythium damping-off by seed-applied bacteria varies with plant species $(17,25)$. In those studies, despite the high levels of disease suppression expressed on plants such as cucumber and cotton, little to no disease suppression was observed on plants such as corn and pea. We would have predicted that the suppression of Pythium damping-off of pea in our municipal biosolids compost would have been lower than that observed on cucumber or wheat. However, the inconsistent but significant levels of disease suppression with pea suggests that the mechanisms by which disease suppression is achieved by the complex microbial communities in compost likely differs from mechanisms of disease suppression by individual microbes.

The main goal of our study was to establish whether seedcolonizing microbial consortia can explain Pythium damping-off suppression in a municipal biosolids compost similar to the suppression observed previously with a leaf compost (22). We chose to pursue this strategy because of the potentially greater success in directly identifying the microbes responsible for Pythium damping-off suppression. Unlike many other studies in which the search for microbes suppressive to a range of diseases has been based on comparisons of microbial taxa present only in the substrate and not associated with plants $(5,6,14,16)$, our approach utilizes our knowledge of the preinfection responses of the pathogen (24) to point not only to the site where disease suppression might be expressed, but also the earliest time at which disease suppression is likely to be expressed.

The germination of sporangia of $P$. ultimum represents an essential and critical step in pathogenesis, with sporangia germinating within minutes of exposure to a seed; germ tubes emerge as early as $30 \mathrm{~min}$ after seed exposure (44). Seeds may be colonized by $P$. ultimum within $1 \mathrm{~h}$ after sowing and nearly $100 \%$ of the seeds colonized by $6 \mathrm{~h}$ (44). High levels of embryo infection follow within 24 to $48 \mathrm{~h}$. Seed exudates regulate these responses (23) and if sporangium germination and subsequent seed colonization are prevented, disease development does not occur. This is particularly clear in biological control studies where some bacterial seed treatments effectively protect plants by eliminating $P$. ultimum germination signals in seed exudates and thus reduce the germination of sporangia (23). Because of the importance of these rapid sporangial responses to disease development, it is logical that the site of any effective microbially mediated suppression of Pythium seed infections is most likely to be in close association with the seed and within hours of sowing.

Both pathogens and nonpathogens respond rapidly to the infusion of seed exudates into the surrounding spermosphere (23). Therefore, compost microbes that colonize seeds in response to such exudates are in an active metabolic state and more likely than many compost-inhabiting microbes to actively suppress Pythium infections. With just bacterial communities alone, there can be potentially more than 10,000 species found in a gram of soil (38), most of which are not likely to be directly involved in disease suppression. By sampling microbial communities at the time and place where suppressiveness is expressed, we can direct 
our microbial community analysis only to those organisms that (i) are in the same habitat as Pythium and are more likely to be involved in interactions with Pythium, (ii) are present at the proper time when Pythium suppressiveness is expressed, (iii) are active against the proper developmental stage of the pathogen, and (iv) interact directly with the plant and plant exudates to influence Pythium activity.

The results of our study demonstrate that microbes from municipal biosolids compost that colonize cucumber and wheat seeds within $8 \mathrm{~h}$ of sowing can explain the damping-off suppression observed in 7-day bioassays. This supports earlier work in which microbial consortia, comprised largely of bacteria and actinobacteria, that colonized cottonseeds within $6 \mathrm{~h}$ of sowing in a Pythium-suppressive leaf compost could explain the dampingoff suppression observed (22). We currently do not know the composition of the microbial consortia associated with cucumber and wheat seeds germinated in municipal biosolids compost. Preliminary evidence suggests that, as with the leaf compost in our previous study, the cucumber seed microbial consortia are comprised largely of bacterial taxa related to Bacillus and actinobacterial species (M.-H. Chen and E. B. Nelson, unpublished data). Although no detectable fungi colonize seeds within an $8 \mathrm{~h}$ incubation in municipal biosolids compost, low fungal populations $\left(\approx 10^{2}\right.$ colony forming units/g) have been detected at the longer incubation times (M.-H. Chen and E. B. Nelson, unpublished data).

Although all of the suppressive activity associated with wheat seeds could be removed by mild vortexing, not all of the suppressive activity could be removed from cucumber seeds in this manner. This indicates that populations of suppressive microbes were retained more strongly on the cucumber seed surface than on the surface of wheat seeds. Evidence for this has come from repeated vortexing treatments in which each vortexing treatment eliminated additional microbial cells from the seed surface and, at the same time, eliminated the suppressiveness retained by the cucumber seeds. This tight adherence of microbial cells to the surface of cucumber seeds may be due to the mucilaginous coating commonly associated with cucurbit seeds (7).

This study has demonstrated the importance of seed-colonizing microbial consortia in the suppression of Pythium damping-off of cucumber and wheat in a municipal biosolids compost. The activity of these microbial consortia do not appear to differ between cucumber and wheat seeds but may be regulated in slightly different ways on pea seeds since damping-off suppression on pea was much more variable. The compositions of the microbial consortia associated with cucumber seeds in the municipal biosolids compost are currently being characterized. Future work examining the dynamics of specific bacterial taxa within consortia associated with seeds in response to differing levels of disease suppression will further verify the role of specific microbial taxa in Pythium damping-off suppression.

\section{ACKNOWLEDGMENTS}

This work was supported by a fellowship awarded to M.-H. Chen by the Taiwan Ministry of Education and by research grant no. IS-3512-04 from BARD, the United States-Israel Binational Agricultural Research and Development Fund. We thank M. A. Karp for technical assistance.

\section{LITERATURE CITED}

1. Ben-Yephet, Y., and Nelson, E. B. 1999. Differential suppression of cucumber damping-off caused by Pythium aphanidermatum, P. irregulare, and P. myriotylum in composts at different temperatures. Plant Dis. 83:356-360.

2. Boehm, M. J., Madden, L. V., and Hoitink, H. A. J. 1993. Effect of organic matter decomposition level on bacterial species diversity and composition in relationship to Pythium damping-off severity. Appl. Environ. Microbiol. 59:4171-4179.
3. Borneman, J., and Becker, J. O. 2007. Identifying microorganisms involved in specific pathogen suppression in soil. Annu. Rev. Phytopathol. 45:153-172.

4. Borneman, J., Olatinwo, R., Yin, B., and Becker, J. O. 2004. An experimental approach for identifying microorganisms involved in specified functions: Utilisation for understanding a nematode suppressive soil. Australas. Plant Pathol. 33:151-155.

5. Borrero, C., Ordovas, J., Trillas, M. I., and Aviles, M. 2006. Tomato Fusarium wilt suppressiveness: The relationship between the organic plant growth media and their microbial communities as characterised by Biolog (R). Soil Biol. Biochem. 38:1631-1637.

6. Borrero, C., Trillas, M. I., Ordovas, J., Tello, J. C., and Aviles, M. 2004. Predictive factors for the suppression of Fusarium wilt of tomato in plant growth media. Phytopathology 94:1094-1101.

7. Bradford, K. J., and Nonogaki, H. 2007. Seed development, dormancy and germination. Vol. 27, Annual Plant Reviews. Blackwell Publishers, Ames, Iowa.

8. Chen, W., Hoitink, H. A. J., Schmitthenner, A. F., and Tuovinen, O. H. 1988. The role of microbial activity in suppression of damping-off caused by Pythium ultimum. Phytopathology 78:314-322.

9. Craft, C. M., and Nelson, E. B. 1996. Microbial properties of composts that suppress damping-off and root rot of creeping bentgrass caused by Pythium graminicola. Appl. Environ. Microbiol. 62:1550-1557.

10. De Ceuster, T. J. J., and Hoitink, H. A. J. 1999. Prospects for composts and biocontrol agents as substitutes for methyl bromide in biological control of plant diseases. Compost Sci. Util. 7:6-15.

11. Ehrenfeld, J. G., Ravit, B., and Elgersma, K. 2005. Feedback in the plantsoil system. Annu. Rev. Environ. Resour. 30:75-115.

12. Garbeva, P., van Veen, J. A., and van Elsas, J. D. 2004. Microbial diversity in soil: Selection of microbial populations by plant and soil type and implications for disease suppressiveness. Annu. Rev. Phytopathol. 42:243270.

13. Garcia, C., Pascual, J. A., Mena, E., and Hernandez, T. 2004. Influence of the stabilisation of organic materials on their biopesticide effect in soils. Bioresour. Technol. 95:215-221.

14. Hjort, K., Lembke, A., Speksnijder, A., Smalla, K., and Jansson, J. K. 2007. Community structure of actively growing bacterial populations in plant pathogen suppressive soil. Microbiol. Ecol. 53:399-413.

15. Hoitink, H. A. J., Krause, M. S., and Han, D. Y. 2001. Spectrum and mechanisms of plant disease control with composts. Pages 263-274 in: Compost Utilization in Horticultural Cropping Systems. P. J. Stofella and B. A. Kahn, eds. Lewis Publishers, Boca Raton, FL.

16. Hunter, P. J., Petch, G. M., Calvo-Bado, L. A., Pettitt, T. R., Parsons, N. R., Morgan, J. A. W., and Whipps, J. M. 2006. Differences in microbial activity and microbial populations of peat associated with suppression of damping-off disease caused by Pythium sylvaticum. Appl. Environ. Microbiol. 72:6452-6460.

17. Kageyama, K., and Nelson, E. B. 2003. Differential inactivation of seed exudate stimulation of Pythium ultimum sporangium germination by Enterobacter cloacae influences biological control efficacy on different plant species. Appl. Environ. Microbiol. 69:1114-1120.

18. Litterick, A. M., Harrier, L., Wallace, P., Watson, C. A., and Wood, M. 2004. The role of uncomposted materials, composts, manures, and compost extracts in reducing pest and disease incidence and severity in sustainable temperate agricultural and horticultural crop production-A review. Crit. Rev. Plant Sci. 23:453-479.

19. Lumsden, R. D., Lewis, J. A., and Millner, P. D. 1983. Effect of composted sewage sludge on several soilborne pathogens and diseases. Phytopathology 73:1543-1548.

20. Maurhofer, M., Keel, C., Haas, D., and Defago, G. 1995. Influence of plant species on disease suppression by Pseudomonas fluorescens strain CHA0 with enhanced antibiotic production. Plant Pathol. 44:40-50.

21. Mazzola, M., and Gu, Y. H. 2002. Wheat genotype-specific induction of soil microbial communities suppressive to disease incited by Rhizoctonia solani anastomosis group (AG)-5 and AG-8. Phytopathology 92:13001307.

22. McKellar, M. E., and Nelson, E. B. 2003. Compost-induced suppression of Pythium damping-off is mediated by fatty-acid-metabolizing seedcolonizing microbial communities. Appl. Environ. Microbiol. 69:452-460.

23. Nelson, E. B. 2004. Microbial dynamics and interactions in the spermosphere. Annu. Rev. Phytopathol. 42:271-309.

24. Nelson, E. B. 2006. Rhizosphere regulation of preinfection behavior of oomycete plant pathogens. Pages 311-341 in: Microbial Activity in the Rhizosphere. K. G. Mukerji, C. Manoharachary, and J. Singh, eds. Springer-Verlag, Berlin.

25. Nelson, E. B., Chao, W. L., Norton, J. M., Nash, G. T., and Harman, G. E. 1986. Attachment of Enterobacter cloacae to hyphae of Pythium ultimum: Possible role in biological control of Pythium pre-emergence dampingoff. Phytopathology 76:327-335.

26. Nelson, E. B., and Craft, C. M. 1989. Comparative germination of 
culture-produced and plant-produced sporangia of Pythium ultimum in response to soluble seed exudates and exudate components. Phytopathology 79:1009-1013.

27. Nelson, E. B., and Hsu, J. S. T. 1994. Nutritional factors affecting responses of sporangia of Pythium ultimum to germination stimulants. Phytopathology 84:677-683.

28. Noble, R., and Coventry, E. 2005. Suppression of soil-borne plant diseases with composts: A review. Biocontrol Sci. Technol. 15:3-20.

29. Pascual, J. A., Hernandez, T., Garcia, C., De Leij, F. A. A. M., and Lynch, J. M. 2000. Long-term suppression of Pythium ultimum in arid soil using fresh and composted municipal wastes. Biol. Fert. Soils 30:478-484.

30. Rotenberg, D., Wells, A. J., Chapman, E. J., Whitfield, A. E., Goodman, R. M., and Cooperband, L. R. 2007. Soil properties associated with organic matter-mediated suppression of bean root rot in field soil amended with fresh and composted paper mill residuals. Soil Biol. Biochem. 39:2936-2948.

31. Scheuerell, S. J., Sullivan, D. M., and Mahaffee, W. F. 2005. Suppression of seedling damping-off caused by Pythium ultimum, $P$ irregulare, and Rhizoctonia solani in container media amended with a diverse range of Pacific northwest compost sources. Phytopathology 95:306-315.

32. Schüler, C., Biala, J., Bruns, C., Gottschall, R., Ahlers, S., and Vogtmann, H. 1989. Suppression of root rot on peas, beans, and beetroots caused by Pythium ultimum and Rhizoctonia solani through the amendment of growing media with composted organic household waste. J. Phytopathol. 127:227-238

33. Schüler, C., Biala, J., and Vogtmann, H. 1989. Antiphytopathogenic properties of biogenic waste compost. Agric. Ecosyst. Environ. 27:477-482.

34. Simon, H. M., Smith, K. P., Dodsworth, J. A., Guenthner, B., Handelsman, J., and Goodman, R. M. 2001. Influence of tomato genotype on growth of inoculated and indigenous bacteria in the spermosphere. Appl. Environ. Microbiol. 67:514-520.

35. Smith, K. P., Handelsman, J., and Goodman, R. M. 1997. Modeling doseresponse relationships in biological control: Partitioning host responses to the pathogen and biocontrol agent. Phytopathology 87:720-729.

36. Sugimoto, E. E., Hoitink, H. A. J., and Tuovinen, O. H. 1990. Oligotrophic pseudomonads in the rhizosphere: Suppressiveness to Pythium damping-off of cucumber seedlings (Cucumis sativus L.). Biol. Fert. Soils 9:231-234.

37. Termorshuizen, A. J., van Rijn, E., van der Gaag, D. J., Alabouvette, C., Chen, Y., Lagerlof, J., Malandrakis, A. A., Paplomatas, E. J., Ramert, B., Ryckeboer, J., Steinberg, C., and Zmora-Nahum, S. 2006. Suppressiveness of 18 composts against 7 pathosystems: Variability in pathogen response. Soil Biol. Biochem. 38:2461-2477.

38. Torsvik, V., Golsoyr, J., and Daae, F. 1990. High diversity in DNA of soil bacteria. Appl. Environ. Microbiol. 56:782-787.

39. van Dijk, K., and Nelson, E. B. 2000. Fatty acid competition as a mechanism by which Enterobacter cloacae suppresses Pythium ultimum sporangium germination and damping-off. Appl. Environ. Microbiol. 66:5340-5347.

40. van Os, G. J., and van Ginkel, J. H. 2001. Suppression of Pythium root rot in bulbous Iris in relation to biomass and activity of the soil microflora. Soil Biol. Biochem. 33:1447-1454.

41. van Rijn, E., Termorshuizen, A. J., and van Bruggen, A. H. C. 2007. Storage method affects disease suppression of flax wilt induced by composts. Soil Biol. Biochem. 39:2743-2749.

42. Veeken, A. H. M., Blok, W. J., Curci, F., Coenen, G. C. M., Termorshuizen, A. J., and Hamelers, H. V. M. 2005. Improving quality of composted biowaste to enhance disease suppressiveness of compostamended, peat-based potting mixes. Soil Biol. Biochem. 37:2131-2140.

43. Weller, D. M., Raaijmakers, J. M., Gardener, B. B. M., and Thomashow, L. S. 2002. Microbial populations responsible for specific soil suppressiveness to plant pathogens. Annu. Rev. Phytopathol. 40:309-348.

44. Windstam, S., and Nelson, E. B. 2008. Differential interference with Pythium ultimum sporangium activation and germination by Enterobacter cloacae in the corn and cucumber spermospheres. Appl. Environ. Microbiol. 74:4285-4291. 